\title{
The Religious Origin of Hollywood Movie with the Theme of Doomsday
}

\author{
Yingjuan Shi \\ School of Foreign Languages \\ Jiangsu university \\ Zhenjiang, China
}

\author{
Xiao Yang \\ College of Continuing Education \\ Nanjing University of Aeronautics \& Astronautics \\ Nanjing, China
}

\begin{abstract}
The end of the world is a recurring theme in the Hollywood disaster film, which criticized the expanding human greed, the control and manipulation of nature and the misunderstanding of technology. This paper presented that the end of the complex in the United States has a more profound religious origin. The basic narrative framework of Hollywood doomsday movie is doomsday, redemption and rebirth, which is consistent with the story of doomsday in the Bible. It was also found that there must be a hero to save the human beings in the disaster, and this kind of character is often based on the prototype of God. It can be concluded that in the field of culture and art, religious consciousness still has a strong influence on the western world.
\end{abstract}

Key words—Doomsday; religion; disaster; Hollywood

\section{INTRODUCTION}

In 2012, it seemed that everyone talked about doomsday and waited for the last ding-dong of doom, which are derived from a Hollywood movie " 2012 ". Over the past few decades, the United States has produced hundreds of disaster films. The so-called disaster film usually tells the horrible and tragic story, that is, nature, human beings, fantasy of extraterrestrial life or modern science and technology bring large-scale disasters to the human society. The disaster theme movie, whether it is based on the history of the real disaster, or from the reality or scientific basis of fiction, has created a large number of classic works. And now, with the rapid development of film technology, computer effects has undoubtedly become an important element of modern movies. The production process of large variety of pipeline scenes is sometimes more charming than the story itself. Moreover, the modern disaster films put on the cloak of doom and won the approval of the world. Hollywood, at the top of entertainment industry chain and with a keen sense in the early 90s, has reflected the ecological crisis in many disaster films. Their bold imagination presented the scene of the last day vividly and cruelly in front of the audience. Chinese audience are familiar with "Independence Day", "the Matrix" series, "Biochemical Crisis" series, "the Day after Tomorrow", "the End of the War", etc.. In the face of the hypothetical disaster, only the American heroes can come forward to save the American people or save the earth. For decades, people's enthusiasm for this kind of film has been increasing. What is puzzling is that, as the world's most powerful, prosperous and liberal country, how Americans can entertain imaginary or groundless fears? We love American movies and admire their imagination and the level of production, but at the same time, we can not be naive to think that the Hollywood movie is just a kind of entertainment industry.

\section{RELIGION-THE ROOT OF THE DOOMSDAY COMPLEX}

In 1990s, the excessive exploitation of human resources on the earth resulted in severe deterioration of the living environment, which caused people's pessimistic attitude towards the future of mankind. In recent years, no matter where we are, we can clearly feel the earth's natural change-earthquakes, tsunamis, floods, droughts, infectious diseases, and so on. On the surface, this is the reason why the disaster films are so popular in US. However, the contemporary science and technology has been quite developed and human beings in the face of natural disasters are not helpless; why do we believe the doomsday prophecy? The answer is religion which is the root of American doomsday complex.

The Last Prophecy in the Bible is called Book of Revelations which included the unprecedented scale of the fire, earthquake, hail, smoke and sulfur, locusts, plague, abnormal high temperature and war, water deterioration killing people, the death of a large number of sea life, etc.. Isn't that what happens in almost all doomsday films? There are many prophecies of doom in the Bible. The Newsweek's poll in December 2004 showed that $55 \%$ of Americans and $83 \%$ evangelical Christians believe that Bible is a true record of history; $61 \%$ of people believe that God created the world in six days; According to the poll of CNN and Time in 2002, $59 \%$ Christian and $77 \%$ the evangelicals believe the prophecy in Book of Revelations will come true.

As we all know, the United States is materialistic; but in fact, the United States is a strong Christian fundamentalist country. Protestantism plays a key role in the American political system, social life, national psychology. American political commentator Kevin Phillips in his book "American theocracy" cited many examples to prove that American theology has replaced the logic, which is no longer a trend, but has gradually evolved into a political and government behavior.

The Declaration of Independence of the United States is deeply influenced by Protestantism. When the founding fathers of the United States wrote the drafting of the 
Declaration of Independence, they make the legitimate basis of founding a country appeal to God and Protestantism in the idea of "natural rights". Christianity holds that all men are created by God, and man is enslaved only by God. Therefore, the Declaration of independence in the United States wrote: "We hold these truths to be self-evident, that all men are created equal, that they are endowed by their Creator with certain unalienable rights, that they are among these are life, liberty and the pursuit of happiness." Modern human rights, freedom, democracy and other ideas actually originated in the Christian religious reform and the formation of the Protestant doctrine which produced the new understanding and interpretation of the bible of the Protestant followers. Therefore, since the founding of the United States, the vast majority of presidents are Christians. At the inauguration of the first president of the United States,George Washington kissed the Bible and took the oath of the Bible. In addition, he said: "I swear, I pray for God's blessing." After that, all the president of the United States followed that way in their inaugural speech, "pray for God's blessing". During the 2000 presidential election, the Pew Research Foundation made a survey on the relationship between voters' attitude and presidential candidate religious belief, which showed up to $70 \%$ of Americans wanted their president to be religious.

Yet the September 11 attacks on the US caused a profound impact to the hearts of most Americans, so that they understand the high-tech can not completely block evil attacks. According to memory of most Americans who witnessed the scene, it happened as if it were the end of the world. In the face of a strong enemy which is so strong that even high-tech can not resist, who will be the first that the Americans ask for help? God, of course. It is the American belief that God can protect them. The religious effects on the society are illusory, but it also plays the role in mapping life. The reflection of religion is the ultimate need of human beings, so it is universal and eternal [1].

The development of modern science and society makes people do things that they could not have dreamed of before. It is easy to think that you can easily get rid of the shackles of nature and religion to play their own will and to control the world. They hoped to establish a human paradise under the concept of "freedom, equality and fraternity". However, there are absurdity and irrationality in historical development process, so people had hoped to use rationality to destroy shackles of religious fantasy for thousands of years; yet the development of the real world and religious prophecy appeared incredibly consistent. The industrial civilization made people low-spirited and decadent; World War destroyed the myth of Western civilization. The so-called freedom, democracy and science was blown into ashes in the fire; idealism has no place to live in in the face of the cruel reality. The spiritual world of human being is in crisis. Therefore, the return of belief is the result of the decline of modern civilization and the way out. The fundamental way to solve the problem of human sin is not to rely on human beings, but to rely on the close relationship between man and God [2].

Religion is actually a very important and basic cultural gene; any kind of long-standing cultural traditions are not lack of religious feelings, but in the different forms [1]. Now the young people in the United States will not be the same as the older generation who were always talking about God, Jesus, faith. the religious belief of the young people is reflected and interpreted in the popular films.

\section{DOOMSDAY, REDEMPTION, REBIRTH}

In Old Testament, God sent flood to clean up the evil of human society; only following God's commands could save the world. Book of Revelation is mainly from the concept of original sin, because people's soul is a pool of pollution and the synthesis of sin. Thus we have to follow the spirit of God, and in the end we could be rescued through self purification. Most people are familiar with the story of Noah's Ark in the bible. The narration of the doomsday has greatly strengthened the religious myth "believe me to be saved". Human beings need the philosophy of religion to appease the anxiety in the turbulent society, and the spread and development of religion needs the universal belief of human beings.

The science fiction film based on the destruction of civilization is known as the post-apocalyptic film, which belongs to a sub genre of science fiction movies. In the west, the core of the so-called post apocalyptic film is naturally christian. Almost all the stories of this kind can be summarized as: doomsday, redemption, rebirth. Taking Water World as an example, we saw the eschatological scene that the earth fell into a world of waters in the beginning of the film. All human beings can strike violently for a little bit of mud and clean water. This is very similar to the flood in the Bible or the apocalyptic scene in Book of Revelation. Then, the child Enola became the key of human being salvation. Finally, under the leadership of hero, the land was finally found and the new life was restored. In the film people saw the flying bird from the land, knowing they were close to the land. The plot is similar to the story of Noah ark in the Bible. Noah sent a dove, and the dove was back with an olive branch, which meant the floods receded. Another interpretation to salvation in doomsday film is the antidote. for example, in the film of Cyborg, the antidote to black death was stored in the electronic brain of the cyborg girl; in the film of Johnny Mnemonic, the antidote to save human beings was stored in the brain of Keanu Reeves. The process of finding a cure is to get rid of the past and acquire a new lease of life. People insist on "good" in the tour of seeking to live on, which is a holy journey to abandon evil soul and to pursuit the pure heart [3].

It is common to believe in the West that civilization is flourishing and then destroyed, which appears again and again. The view on this cycle of civilization in western society is quite common. When they study the history of the Empire of Rome and the Egyptian Dynasty, what they saw is the rise and decline of civilization. Most people who believe doomsday are not satisfied with the current situation. They think the world is too ugly and evil, so it should be destroyed, and let the human be reborn. Therefore, the doomsday film always get a happy ending, bringing the audience infinite hope. 


\section{JeSUS - ThE PROTOTYPE OF THE HERO IN THE DOOMSDAY MOVIE}

In many disaster films, when the human world faces the brink of destruction, there will be a hero to save the mankind. In fact, Jesus is the prototype for the hero in the Hollywood movie. Jesus, the hero of the western world can let the human be saved from sin and death and will be remembered throughout the ages. Almost all the super heroes has a similar fate with Jesus.

The broken family-Jesus had no father, and the superheroes usually lost their parents in childhood and had no family. Superman's father died in the explosion of krypton ; Batman witnessed his parents were killed in the childhood ; spider man, since his parents died, raised by his uncle and aunt, but his uncle was killed by robbers. Broken family background is extremely easy to cause their hatred of evil and desire for doing good.

Civilian identity-Jesus was born in Bethlehem and grew up just a carpenter, but he came to Jerusalem to preach about 30 years old. Superheroes are also ordinary people on weekdays. Superman is a shy reporter; spider man is a poor student; only Batman is considered as a lonely rich two generation. They are basically in a weak position in real life, and are civilian heroes.

Redeeming mankind-when human beings cannot extricate themselves of $\sin$ and death, Jesus showed a life force and was crucified in order to save humanity. Super heroes are also subjected to physical torture or heart attack. After wandering and shilly-shally, they realized a self redemption and personal value, through the magic power and self sacrifice for the salvation of mankind.

Jesus, used as a prototype to create a series of super heroes, embodies the spirit of individualism, moralism, patriotism and heroism. The civilian heroes narrow the gap between the hero and the ordinary people, and let people feel everyone could become the hero to save the world. And the affirmation of individual value of the United States strengthens the significance of civilian hero. It appears that the civilian identity and their success story is the most logical and inspiring [4].

\section{RELIGION AND THE POSITIVE SIGNIFICANCE OF DOOMSDAY}

In any society, human beings are under the double oppression of nature and society, which makes people live in the fear of the alien forces. until today with highly developed science and technology, modern people will also have a fear of natural disasters and social disasters. Therefore, people need some means to relieve stress and fear. One of the most important functions of religion is to provide psychological comfort and security for the members of the society with the help of the power of the super human [5]. In the face of the ontological anxiety of human beings, religious beliefs can help mankind to overcome the difficulties of fate and meaningless anxiety.

The cause of the end of the world is the sharp contradiction and abnormal disconnect in man and nature, man and society, man and man and man and themselves. After the disaster, human beings become more mature. Disaster also reminds us how to take care of their homes and how to protect the natural environment, so that the human world becomes more harmonious. When the disaster was approaching in the film, human beings had to struggle for the survival, which confirmed that the hope inside of the human heart would not fly away. The commercial movies with blood, violence and horror to win the audience truly fulfilled its duties and responsibilities as contemporary disaster revelation [6].

Doomsday complex does not mean nothing, but like a mirror, let us think about the meaning of life and allow us to find the real needs of our hearts. The doomsday movie often introspect the real world and the dependence relationship between human and society through the journey of doomsday, redemption, rebirth. Only when we grasp the deep structure of the journey, can we realize the metaphor of such movies. If everyone has a positive attitude of the end of the world, then the world will be obtain a new life and welcome a new civilization like the Mayan prophecy.

\section{CONCLUSION}

The western world has a close relationship with the understanding of eschatology and the Bible. There is a clear record of the real world in the Bible that when the day is approaching, everything will be changed and a new world is coming. In the long history, religion and culture has always been accompanied. As a kind of social ideology, religion and spiritual culture influence each other. Religious emotion will not only affect the national emotion, but also have a profound impact on aesthetic taste, values, ethics, customs and habits. Therefore, the Hollywood movie theme will inevitably be irradiated by religion; at the same time, such plot design in the context of religious origin can also obtain the audience's confirmation, especially for those who seem to fall into the plight of the end of the world.

\section{REFERENCES}

[1] S. J. He, "The spiritual connotation of contemporary novels from the perspective of religious feelings", Beijing: Literature and Art Research, April 2004, pp. 23-28.

[2] Y. Liu , The Beginning of Modern Criticism: A Study of T.S.'s Poetics by Eliot, Nanning: Guangxi Normal University Press, 2005, pp. $122-126$.

[3] A. H. Chen, "Exploration of human nature under the cloak of violence", Xi'an: Journal of PLA Foreign Languages Institute", January 2013, pp. 18-25.

[4] L. Lee, "The identification of civilian heroes in American movies", Beijing: People's Forum. September 2012, pp. 28-33.

[5] S. Y. Sun, Religious Sociology. Beijing: Peking University Press, 2015, pp. 123-133.

[6] M. Lee, "The biochemical theme film and contemporary spiritual disaster apocalypse", Changchun: Film Literature, December 2013, pp. 37-43. 